\title{
MANAGEMENT OF DIGITAL BUSINESS IN THE CONTEXT OF COUNTRY'S ECONOMIC DEVELOPMENT ${ }^{1}$
}

The key role of information and communication technologies in ensuring sustainable economic development of the country is identified. It is formulated and justifiably proven the hypothesis about the existence of a direct relationship between the Information and Communication Technologies Development Index, the Digital Competitiveness of the country and the Global Competitiveness Index of the country. Considering the ability of digital business to have a significant impact to the country's economic development, the conceptual basis of digital business management (considered on the example of online retail) is proposed. It is determined the specifics of interaction between the participants of digital business in accordance with the fundamental principles of digital business management, that involve the use of appropriate tools and a portfolio of relevant methods for managing digital business.

Key words: country's economic development, information and communication technologies, digital competitiveness, digital business, conceptual basis of digital business management.

\section{DOI: 10.15276/mdt.2.4.2018.6}

Statement of the problem in general form and it's connection with important scientific or practical tasks. In the context of globalization, the economic development of any country is determined by information and communication technologies, and, consequently, their level of use by market actors in their own activity. Nowadays it is possible to observe a mass digitalization of market entities activity based on their desire to quickly adapt to changes in the digital age. Therefore, the study of questions about the desirability of digitalization of market entities activity and considering aspects of digital business management.

Analysis of the latest research and publications, which initiated the solution of this problem and on which the author relies. The studies of leading foreign scientists and economists are dedicated to the theoretical and methodological aspects of market entities digitalization in various sectors of the economy, among whom: Barefoot K. (2018), Bris A. (2016), Caballero J. (2016), Cabolis C. (2016), Curtis D. (2018), Fenwick N. (2015), Jolliff W. (2018), Kaplan J. (2012), Nicholson J. (2018), Omohundro R. (2018), Sharma Sh. (2012), Weinberg A. (2012). However, the problem about the digital business influence on a country's economy, as well as its rational management, is currently relevant and requires detailed study.

(C) 2018 The Authors. This is an open access article under the CC BY license (http://creativecommons.org/licenses/by/4.0/)

\footnotetext{
1 The publication contains the results of studies conducted by President's of Ukraine grant for competitive projects F75 of the State Fund for Fundamental Research.
} 
Formulation of the purposes of the article (statement of the problem). The purposes of the article are to identify the factors influencing a country's economy and to justify the conceptual basis of digital business management in order to ensure positive economic development of the country. The objects of the study are the countries of the Organization for Economic Cooperation and Development (OECD) and Ukraine.

Statement of the main material of the research with full justification of the scientific results obtained. Today, the development of information and communication technologies (ICT) determines the welfare of any country and is a defining characteristic of its economy development. The degree of online interaction in society is increasing with the emergence and active implementation of new ICT.

According to the data of the World Economic Forum (2018), to the end of 20178 billion gadgets and devices in the world will be connected to the Internet, and by 2030, and it is projected that this number will increase to 1 trillion. Therefore, the monitoring of the ICT development, which affects all areas of activity on the market, is an important component of the government policy.

The country's ICT development index is a powerful tool for monitoring progress towards a global information society. It allows countries to track their progress in the development of ICT infrastructure, the use of ICT skills on an annual basis and to adjust policies for the ICT and telecommunications sector. That's why the country's ICT development index is a composite indicator that is determined and published by International Telecommunication Union (ITU).

The ICT Development Index (IDI, 2018), which has been published annually since 2009 , is a significant index that combines indicators into one benchmark measure. It is used to monitor and compare developments in ICT between countries and over time. The main objectives of the IDI are to measure:

- the level and evolution over time of ICT developments within countries and the experience of those countries relative to others;

- progress in ICT development in both developed and developing countries;

- the digital divide, i.e. differences between countries in terms of their levels of ICT development;

- the development potential of ICTs and the extent to which countries can make use of them to enhance growth and development in the context of available capabilities and skills.

The IDI is designed to be global and reflect changes taking place in countries at different levels of ICT development. Therefore, it relies on a limited set of data which can be established with reasonable confidence in countries at all levels of development.

Based on this conceptual framework, the IDI is divided into the following three subindices, which include 11 indicators:

1. Access sub-index: This sub-index captures ICT readiness and includes five infrastructure and access indicators (fixed-telephone subscriptions, mobile-cellular telephone subscriptions, international Internet bandwidth per Internet user, households with a computer, and households with Internet access).

2. Use sub-index: This sub-index captures ICT intensity and includes three intensity and usage indicators (individuals using the Internet, fixed broadband subscriptions, and mobile-broadband subscriptions).

3. Skills sub-index: This sub-index seeks to capture capabilities or skills which are important for ICTs. It includes three proxy indicators (mean years of schooling, gross secondary enrolment, and gross tertiary enrolment). As these are proxy indicators, rather than indicators directly measuring ICT-related skills, the skills sub-index is given less weight in the computation of the IDI than the other two sub-indices. 
As noted Christos Cabolis (2017), Adjunct Professor of Economics and Competitiveness at the International Institute for Management Development (IMD World Competitiveness Center, 2018), governments around the world are investing heavily on the enhancement of their digital economy in order to augment value creation and prosperity in their countries. While the existence of a particular technology is an essential and necessary condition for the future well-being of a nation, it is not sufficient. Digital technology needs not only to be implemented, but also to be explored in order to achieve two important goals: first, to improve efficiency, and second, to enhance both the range as well as the quality of services provided to citizens and businesses alike.

Therefore, in order to assess the capacity and readiness of a country to adapt, explore and make the most of the digital transformation, the IMD World Competitiveness Center is introducing a report «The World Digital Competitiveness Ranking» (2017). The Ranking provides a measure of a country's ability to adopt and explore digital technologies leading to transformation in government practices, business models and society in general.

The Digital Competitiveness Ranking is based on 50 indicators which are grouped in nine sub-factors that, in turn, are classified in three factors: (1) knowledge - reflects a country's capacity to understand and learn new technologies; (2) technology environment measures ability of an economy to develop digital innovations; (3) future readiness - reflects the readiness of an economy for the coming developments.

The factors and nine sub-factors in the structure of the Digital Completeness are described below:

1. Knowledge (talent, training/education investment, scientific concentration).

2. Technology environment (supportive regulatory framework, capital, technological framework).

3. Future readiness (adaptive attitudes, business agility, IT integration).

Monitoring of countries' position in The World Digital Competitiveness Ranking is important in modern conditions. High positions in the ranking of countries indicate an active sustainable development of the economy and its components, including digital business. The evaluation of Digital Competitiveness allows identifying factors constraining the development of the usage and implementation of ICT in the country and helping countries to formulate a list of further action directions.

In the article for research and analysis the IDI and the Digital Competitiveness were selected 37 OECD countries and Ukraine, taking into account their active cooperation in accordance with the Memorandum of understanding signed between Government of Ukraine and OECD (2014). Also, it should be mentioned that OECD activities are aimed at strengthening and improving the efficiency of member economies, improving socio-economic and employment conditions, ensuring economic growth in both industrialized countries and developing countries (Permanent Mission of Ukraine to the UNESCO, 2018).

So, the Table 1 shows the IDI and the Digital Competitiveness of OECD countries in comparison with Ukraine in 2017.

According to the Table 1, only two of OECD countries in 2017 had the IDI below Ukraine, namely Mexico and Colombia, their IDI were 5.2 and 5.4, respectively, against Ukraine IDI - 5.6. This value of Ukraine IDI is due to the low the IDI Use (Sub-Index 2), that was 3.2. It can be stated that Ukraine IDI Use (Sub-Index 2) was the lowest among the compared countries, because the country has a small percentage of coverage of the Internet and, as a consequence, a low level of involvement of the population in the use of the Internet. In 2017, Iceland had the highest IDI value -9.0. This indicates the high level of ICT usage in the country and the optimal coverage of the Internet in the country, as well as the high level of Internet security provided by the Internet with its maximum involvement in usage. 
Table 1 - The IDI and the Digital Competitiveness of countries, 2017

\begin{tabular}{|c|c|c|c|c|c|c|c|c|c|c|c|}
\hline Country & $\overline{\hat{\theta}}$ & 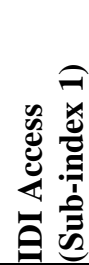 & 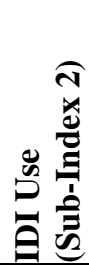 & 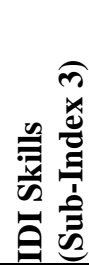 & 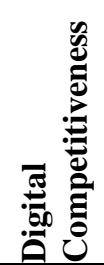 & Country & 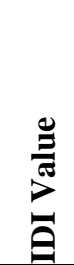 & 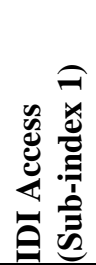 & 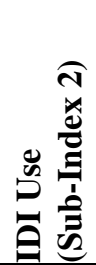 & 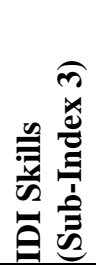 & 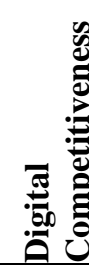 \\
\hline Australia & $8 . \overline{2}$ & 8.0 & 8.0 & 9.3 & 85.0 & Latvia & 7.3 & 7.4 & 6.7 & 8.2 & 67.7 \\
\hline Austria & 8.0 & 8.4 & 7.4 & 8.6 & 84.1 & Lithuania & 7.2 & 7.1 & 6.6 & 8.4 & 75.0 \\
\hline Belgium & 7.8 & 8.2 & 7.2 & 8.3 & 80.8 & Luxembourg & 8.5 & 9.5 & 8.3 & 6.7 & 82.9 \\
\hline Canada & 7.8 & 7.9 & 7.3 & 8.5 & 91.7 & Mexico & 5.2 & 5.3 & 4.7 & 5.9 & 54.5 \\
\hline Chile & 6.6 & 6.8 & 5.4 & 8.5 & 65.4 & Netherlands & 8.5 & 8.7 & 8.3 & 8.6 & 93.2 \\
\hline Colombia & 5.4 & 5.9 & 4.1 & 6.8 & 48.5 & New Zealand & 8.3 & 8.3 & 8.1 & 8.8 & 85.2 \\
\hline $\begin{array}{l}\text { Czech } \\
\text { Republic }\end{array}$ & 7.2 & 7.1 & 6.6 & 8.3 & 70.6 & Norway & 8.5 & 8.0 & 8.8 & 8.7 & 90.8 \\
\hline Denmark & 8.7 & 8.4 & 8.9 & 8.9 & 94.5 & Poland & 6.9 & 7.6 & 5.5 & 8.4 & 65.9 \\
\hline Estonia & 8.1 & 8.2 & 8.0 & 8.4 & 78.5 & Portugal & 7.1 & 7.9 & 6.2 & 7.5 & 69.7 \\
\hline Finland & 7.9 & 7.4 & 8.0 & 8.7 & 95.0 & Slovakia & 7.1 & 7.2 & 6.7 & 7.5 & 59.3 \\
\hline France & 8.2 & 8.6 & 7.9 & 8.1 & 78.8 & Slovenia & 7.4 & 7.9 & 6.2 & 8.8 & 68.7 \\
\hline Germany & 8.4 & 8.9 & 7.8 & 8.5 & 84.1 & South Korea & 8.9 & 8.9 & 8.7 & 9.2 & 83.0 \\
\hline Greece & 7.2 & 7.8 & 5.8 & 9.0 & 54.4 & Spain & 7.8 & 8.0 & 7.2 & 8.5 & 72.1 \\
\hline Hungary & 6.9 & 7.8 & 5.7 & 7.7 & 58.5 & Sweden & 8.4 & 8.6 & 8.4 & 8.2 & 95.9 \\
\hline Iceland & 9.0 & 9.4 & 8.7 & 8.8 & 80.5 & Switzerland & 8.7 & 8.9 & 8.9 & 8.2 & 92.0 \\
\hline Ireland & 8.0 & 8.1 & 7.6 & 8.7 & 82.9 & Turkey & 6.1 & 6.3 & 4.9 & 8.0 & 53.9 \\
\hline Israel & 7.9 & 8.2 & 7.3 & 8.4 & 86.7 & Ukraine & 5.6 & 6.6 & 3.2 & 8.6 & 44.0 \\
\hline Italy & 7.0 & 7.3 & 6.4 & 7.9 & 65.5 & $\begin{array}{l}\text { United } \\
\text { Kingdom }\end{array}$ & 8.7 & 9.2 & 8.4 & 8.2 & 88.9 \\
\hline Japan & 8.4 & 8.8 & 8.2 & 8.2 & 78.1 & United States & 8.2 & 8.3 & 7.7 & 9.1 & 95.4 \\
\hline
\end{tabular}

Source: The ICT Development Index (2017); The IMD World Digital Competitiveness Ranking (2017)

Also, the data in the Table 1 indicate that Ukraine in 2017 had the lowest Digital Competitiveness compared to other OECD countries. It was equal to 44.0. This is because Ukraine had an insufficiently developed supportive regulatory framework, a weak IT infrastructure, and a small amount of investment in the development of digital activities. However, Ukraine had a sufficient number of competent highly skilled workers and all other necessary resources for the implementation of digital activities in 2017. With this in mind to increase the IDI, Ukraine has to increase the number of fixed and mobile broadband Internet subscribers, and to develop and implement strategic and operational action plans.

The highest level of the Digital Competitiveness had Sweden among the countries represented in the Table 1, which was 0.5 higher than the value of the Digital Competitiveness of the United States. That is, the level of the Digital Competitiveness of Sweden and United States in 2017 were more than twice as high as Ukraine. Therefore, Ukraine needs to plan and implement a set of strategic and tactical measures to increase the level of the Digital Competitiveness in the future.

In general, based on the results of the analysis of the Table 1, we can formulate the hypothesis 1 about a certain relationship between the IDI and the Digital Competitiveness the higher the IDI the country has, the higher its Digital Competitiveness.

It was conducted a correlation analysis to test the hypothesis 1. Figure 1 shows a graphical interpretation of the relationship between the IDI and the Digital Competitiveness of OECD countries and Ukraine in 2017.

A. Natorina. Management of digital business in the context of country's economic 


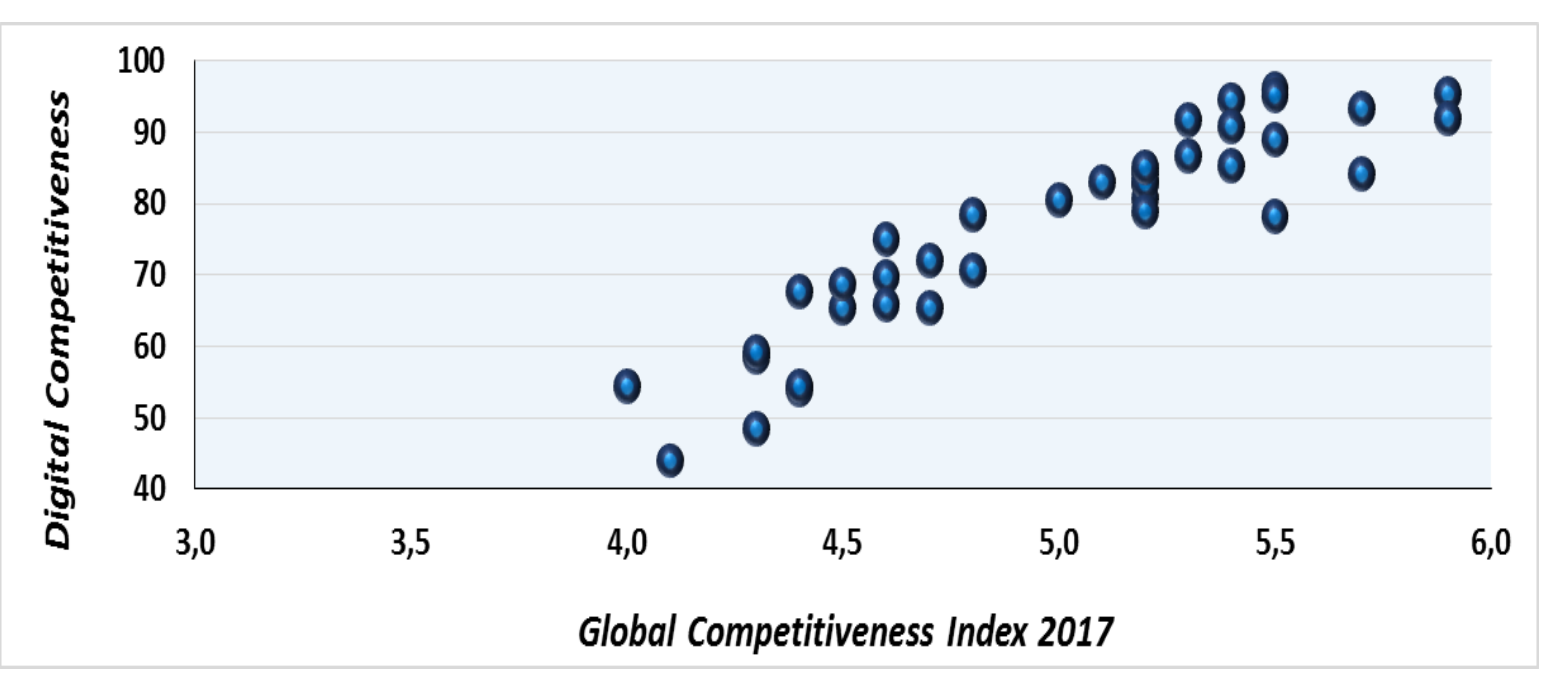

Figure 1 - Dependence between the IDI and the Digital Competitiveness of OECD countries and Ukraine, 2017

Source: composed by the author according to The ICT Development Index (2017); The IMD World Digital Competitiveness Ranking (2017)

Based on the results of the calculations, it is determined that the correlation is linear and positive, and the actual value of the Student's t-test exceeds the critical value. Since the actual value of the Spearman rank correlation coefficient exceeds the critical value, the correlation between the IDI and the Digital Competitiveness of the OECD countries and Ukraine in 2017 was significant at a probability level of 95\%. Thus, it can be argued that the value of the IDI, which depends on the level of ICT use and implementation, has a direct relationship with the Digital Competitiveness of the country.

The level of development and the degree of ICT use in the country affects its competitiveness. The proof of this is that, according to the methodology for determining the Global Competitiveness Index (GCI) of the country (The Global Competitiveness Report, 2017), the Technological readiness of the country - 9th pillar of the GCI. The technological readiness is only a certain percentage of the GCI which is determined by such components: (1) technological adoption (availability of latest technologies; firm-level technology absorption; FDI and technology transfer); (2) ICT use (Internet users; fixed-broadband Internet subscriptions; Internet bandwidth; mobile-broadband subscriptions).

The following Table 2, showing the GCI, the Technological readiness of OECD countries and Ukraine in 2017.

According to the analysis of the data (Table 2), it can be concluded that Ukraine GCI in 2017 was lower than in 35 other OECD countries, except Greece. Ukraine GCI was 4.1, and the Greece GCI - 4.0, which is only 0.1 less than in Ukraine. Such Ukraine GCI in 2017 is explained by the low value of 9th GCI pillar Technological readiness, namely the mobilebroadband subscriptions. It should be noted that Switzerland and the United States had the highest GCI values among the countries studied. Their GCI in 2017 was 5.9, which indicates the positive impact of ICT on the countries' economies, including the massive ICT implementation into business. Therefore, to increase Ukraine GCI it is necessary:

- to increase the level of ICT usage in the interaction of various actors in the market;

- to focus on the development of new ICT market actors;

- to direct the state's internal policy to support and develop digital business. 
Table 2 - The GCI, the Technological readiness of OECD countries and Ukraine, 2017

\begin{tabular}{|c|c|c|c|c|c|c|c|c|c|}
\hline Country & 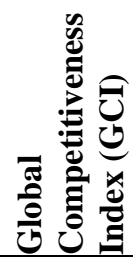 & 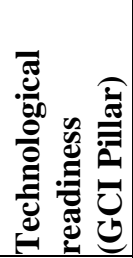 & 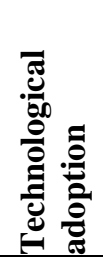 & 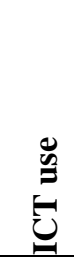 & Country & 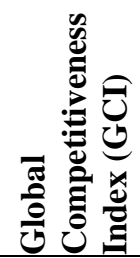 & 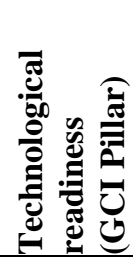 & 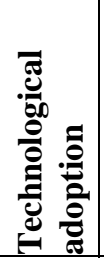 & 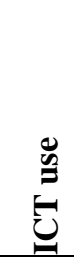 \\
\hline Australia & 5.2 & $5 . \overline{7}$ & 5.3 & 6.1 & Latvia & 4.4 & 5.3 & 4.7 & 5.9 \\
\hline Austria & 5.2 & 6.0 & 5.3 & 6.6 & Lithuania & 4.6 & 5.6 & 5.3 & 6.0 \\
\hline Belgium & 5.2 & 5.9 & 5.6 & 6.3 & Luxembourg & 5.2 & 6.5 & 5.9 & 7.0 \\
\hline Canada & 5.3 & 5.9 & 5.5 & 6.2 & Mexico & 4.4 & 4.2 & 4.9 & 3.5 \\
\hline Chile & 4.7 & 5.2 & 5.3 & 5.1 & Netherlands & 5.7 & 6.3 & 5.9 & 6.8 \\
\hline Colombia & 4.3 & 4.3 & 4.3 & 4.4 & New Zealand & 5.4 & 6.1 & 5.6 & 6.6 \\
\hline $\begin{array}{l}\text { Czech } \\
\text { Republic }\end{array}$ & 4.8 & 5.5 & 5.2 & 5.8 & Norway & 5.4 & 6.1 & 5.8 & 6.4 \\
\hline Denmark & 5.4 & 6.1 & 5.6 & 6.6 & Poland & 4.6 & 4.9 & 4.8 & 5.0 \\
\hline Estonia & 4.8 & 5.9 & 5.3 & 6.6 & Portugal & 4.6 & 5.7 & 5.5 & 6.0 \\
\hline Finland & 5.5 & 6.0 & 5.7 & 6.2 & Slovakia & 4.3 & 5.1 & 5.1 & 5.0 \\
\hline France & 5.2 & 5.9 & 5.4 & 6.4 & Slovenia & 4.5 & 5.4 & 4.9 & 5.8 \\
\hline Germany & 5.7 & 6.2 & 5.7 & 6.6 & South Korea & 5.1 & 5.6 & 5.2 & 6.1 \\
\hline Greece & 4.0 & 4.8 & 4.3 & 5.3 & Spain & 4.7 & 5.7 & 5.0 & 6.4 \\
\hline Hungary & 4.3 & 5.1 & 4.6 & 5.6 & Sweden & 5.5 & 6.3 & 5.9 & 6.7 \\
\hline Iceland & 5.0 & 6.2 & 5.5 & 6.8 & Switzerland & 5.9 & 6.4 & 5.9 & 6.8 \\
\hline Ireland & 5.2 & 6.0 & 5.7 & 6.3 & Turkey & 4.4 & 4.4 & 4.7 & 4.1 \\
\hline Israel & 5.3 & 6.2 & 5.9 & 6.4 & Ukraine & 4.1 & 3.8 & 4.0 & 3.7 \\
\hline Italy & 4.5 & 5.1 & 4.6 & 5.6 & United Kingdom & 5.5 & 6.3 & 5.8 & 6.8 \\
\hline Japan & 5.5 & 6.0 & 5.6 & 6.4 & United States & 5.9 & 6.2 & 6.0 & 6.5 \\
\hline
\end{tabular}

Source: composed by the author according to The Global Competitiveness Report (2017)

Based on the results of the analysis of the GCI, the Technological readiness of OECD countries and Ukraine in 2017 (Table 2), it is possible to formulate a hypothesis 2 - the country's Digital Competitiveness affects the overall competitiveness of the country and, as a consequence, the country's GCI. Figure 2 shows a graphical interpretation of the dependence of the Digital Competitiveness and the GCI of the studied countries.

To test the hypothesis 2, it was identified the existence of a correlation between the GCI and the Digital Competitiveness of OECD countries and Ukraine in 2017. The calculations allowed to establish that the correlation connection is strong, linear and positive. The correlation relationship is significant at $95 \%$ probability level because the actual value of the Student's t-test exceeds the critical value, and the actual value of the Spearman rank correlation coefficient exceeds the critical value. Consequently, the hypothesis 2 about the existence of a dependence between the GCI and the Digital Competitiveness of countries was proved.

Taking into account the aforementioned, as well as the fact that the conduct of digital business has a significant effect on the country's economic development, it can be argued that the substantiation and implementation of the conceptual principles of digital business management will significantly affect the Digital Competitiveness of the country as a whole and increase its GCI due to the existence of the interconnection between them.

Therefore, in the article the conceptual basis of digital business management, that considered on the example of online retail is justified (Figure 2). 
120,0

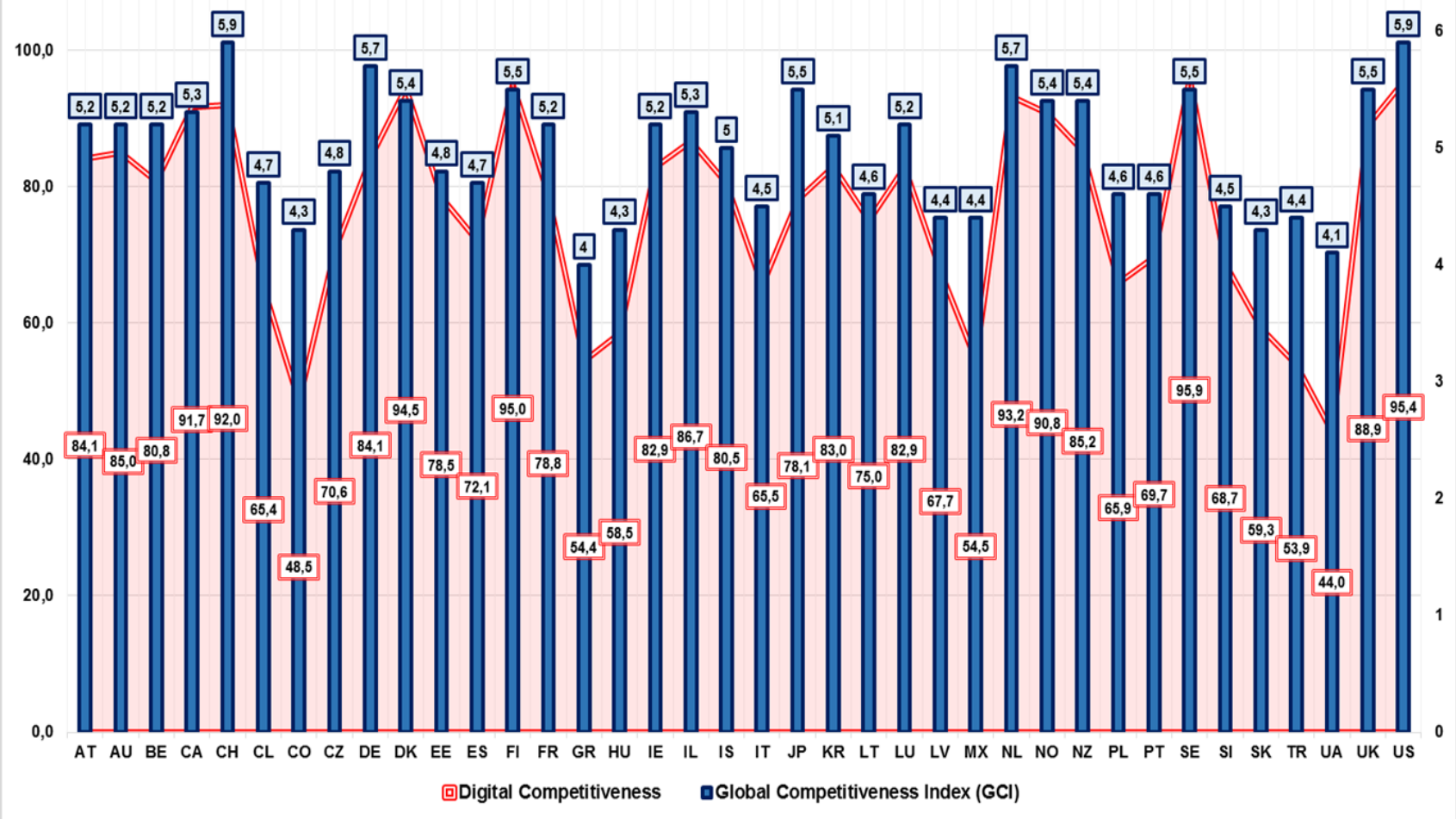

Notes: Australia - AU, Austria - AT, Belgium - BE, Canada - CA, Chile - CL, Colombia - CO, Czech Republic - CZ, Denmark - DK, Estonia - EE, Finland - FI, France FR, Germany - DE, Greece - GR, Hungary - HU, Iceland - IS, Ireland - IE, Israel - IL, Italy - IT, Japan - JP, Latvia - LV, Lithuania - LT, Luxembourg - LU, Mexico - MX, Netherlands - NL, New Zealand - NZ, Norway - NO, Poland - PL, Portugal - PT, Slovakia - SK, Slovenia - SI, South Korea - KR, Spain - ES, Sweden - SE, Switzerland - CH, Turkey - TR, Ukraine - UA, United Kingdom - UK, United States - US.

Figure 2 - The Digital Competitiveness and GCI of OECD countries and Ukraine, 2017

Source: composed by the author according to The IMD World Digital Competitiveness Ranking (2017); The Global Competitiveness Report (2017)

The conceptual basis of digital business management represents a symbiosis of aim; object; subject; levels of management; factors of influence; mechanism; toolkit; principles; methods; priority guidelines of interaction between digital business participants.

According to the Figure 3, the fundamental principles of digital business management:

1. Focus. The digital business management at all its hierarchical levels should ensure the rapid realization of the specific objectives of each level that involves implementation of a number of tasks and appropriate marketing activities.

2. Complexity. Substantiation and management decision making in the field of digital business must necessarily be complex. Only a comprehensive understanding of the digital business effectiveness will ensure the integrity of its structure and predict the possible consequences for the conduct of digital business, as well as develop further steps for its further stable development in the market. 


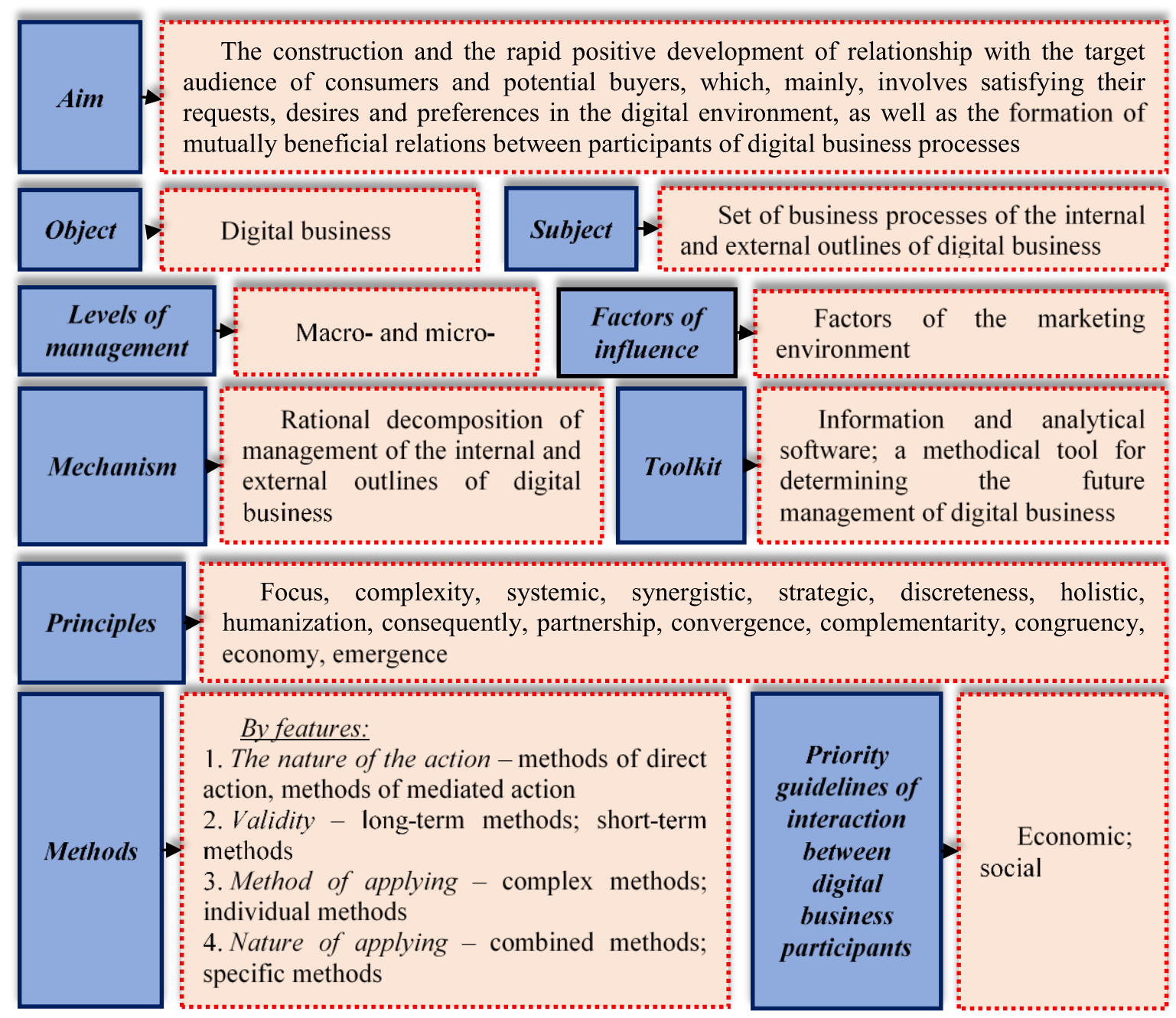

Source: composed by the author

Figure 3 - The conceptual basis of digital business management (considered on the example of online retail)

3. Systemic. To manage digital business, it is expedient to consider its internal and external outlines as a whole. This will neglect the negative influence of the marketing environment factors at the results of the implementation of a range of relevant events in the market.

4. Synergistic. Increasing the digital business competitiveness due to symbiosis of digital and offline business, which enables to significantly increase the existing consumers target audience by achieving the continuous massification of goods and / or services.

5. Strategic. It means the ability of the management team to make strategic decisions regarding the digital business development in the future and take into account economic bifurcations and generate a strategic plan for the digital business development with possible strategic changes in marketing policies that directly depends on the requests, requirements and preferences of consumers.

6. Discreteness. Digital business management involves the consideration of the permanent influence of the marketing environment factors, that is, factors of direct and indirect influence. Therefore, the adoption of strategic and tactical decisions in the field of 
digital business management should take into account the time discreteness of market functioning.

7. Holistic. Identifying the role of each of the participants in the digital business processes and recognizing the key role of consumers, vendors and other parties in conducting digital business, allow companies to provide products and / or services expected in their view of quality and value in the market. This stipulates the need to take into account the principle of holistic behavior in the management of digital business.

8. Humanization. The digital business management, first of all, determines the priority in satisfying the demands, requirements and preferences of consumers, as well as all participants of contact and interaction with the digital business, which allow to constantly improve activity in the market; correctly determine the vectors and trajectory of further business actions, which, in turn, help to increase the level of competitiveness and efficiency of conducting digital business.

9. Consequently. The digital business management provides for the consistent implementation of strategic and tactical market plans, that is, the consistent and phased realization of a number of tasks, taking into account the direct and reverse links between the internal and external outlines of digital business without disrupting their continuity.

10. Partnership. This principle of digital business management taking into account the interests of all market participants that are directly related to the conduct of digital business. This, in turn, contributes to the continuous modernization of the digital partnership mechanism in conditions of constant gradual digital transformation, aimed at mutual consideration and satisfaction of all participants.

11. Convergence - simultaneous combination of the constitutive attributes of digital business with other forms of offline business in order to increase the efficiency of activities by increasing the coverage of consumers and, consequently, scaling.

12. Complementarity. Digital business management takes into consideration maximum satisfaction of online consumer preferences and should also aim at attracting the proportion of offline consumers who use online goods and / or online services on a temporary basis. This will ensure flexible adaptation of digital business to the external environment and increase its productivity in the market.

13. Congruency. Successful management of digital business is based on the implementation of adequate coordinated and consistent strategies among its various components, allowing to meet the market requirements of the present.

14. Economy. Minimizing the costs associated with the implementation of a set of tasks and marketing efforts aimed to achieve the general objective at each stage of the digital business development.

15. Emergence. Thorough management decisions in the field of digital business must take into account its structural components, that are determined by specific properties and affect the overall market performance.

The principles of digital business management that proposed and interpreted in the article should be consistent with each other. They should not contradict each other, so that their implementation contributes to the rational conduct of digital business in the market and the achievement of the general goal, that is, the planned result of management. Also, the above principles are a prerequisite for the use of a portfolio of relevant methods and tools for managing digital business.

The author also defined the specifics of interaction between the participants of digital business in accordance with the conceptual principles of digital business management:

- increased communication activity (contact with a significant ever-changing number of participants in digital business); 
- complexity given the variability of management decisions and the likelihood of various risks arising in the management of digital business;

- personalization and individualization;

- high level of concatenation;

- accumulation and aggregation of a large number of participants' data;

- permanent information support of all business operations and business processes.

\section{Conclusions from this research.}

1. Based on the results of the study, two hypotheses were formulated and proved:

- hypothesis 1 - the IDI and the Digital Competitiveness of the country have a certain relationship - the higher the IDI the country has, the higher its Digital Competitiveness;

- hypothesis 2 - The country's Digital Competitiveness affects the overall competitiveness of the country and, as a consequence, the GCI country.

2. The conceptual basis of digital business management (considered on the example of online retail) is justified, which represents a symbiosis of aim; object; subject; levels of management; factors of influence; mechanism; toolkit; principles; methods; priority guidelines of interaction between digital business participants. In addition, it is defined the specifics of interaction between the participants of digital business in accordance with the conceptual principles of digital business management.

3. The implementation of the basis of digital business management will have a positive impact on the country's economic development, in particularly; it will affect the country's Digital Competitiveness and allow to increase its GCI.

1. Barefoot, K., Curtis D., Jolliff, W., Nicholson, J., \& Omohundro, R. (2018). Defining and Measuring the Digital Economy. Bureau of Economic Analysis. Retrieved from: https://www.bea.gov/digital-economy/_pdf/defining-and-measuring-the-digital-economy.pdf.

2. Bris, A., Cabolis, C., \& Caballero, J. (2016). Structure and Drivers of Digital Competitiveness. IMD Center Research. Retrieved from: https://www.imd.org/wcc/world-competitiveness-centerpublications/oct-2016-criterion.

3. Cabolis, C. (2017). A new publication at the IMD World Competitiveness Center: The World Digital Competitiveness Ranking. IMD Center Research. Retrieved from: https://www.imd.org/wcc/world-competitiveness-center-publications/2017-com-may.

4. Fenwick, N., Matzke, P., Mulpuru, S., Gill, M., Wang, Ch., Klehm, R. \& Traikovich, K. (2015). The State of Digital Business To 2020 By 2020. Execs Expect To See The Majority Of Their Revenues Driven By Digital - Are You Ready? Retrieved from: https://www2.simplermedia.com/rs/706-YIA261/images/StateofDigitalForresterReport-Dynatrace.pdf.

5. IMD World Competitiveness Center (2018). www.imd.org Retrieved from: https://www.imd.org/ 6. International Telecommunication Union (ITU) (2018). www.itu.int Retrieved from: https://www.itu. int.

7. McKinsey Center for Business Technology (2012). Perspectives on Digital Business. www.mckinsey.com Retrieved from: https://www.mckinsey.com/ /media/mckinsey/dotcom/client_ service/BTO/PDF/MCBT_Compendium_Perspectives_on_Digital_Business.ashx.

8. Memorandum of understanding signed between Government of Ukraine and OECD (2014). zakon0.rada.gov.ua Retrieved from: http://zakon0.rada.gov.ua/laws/show/966_003.

9. Spivrobitny'cztvo v ramkax Organizaciyi Ekonomichnogo spivrobitny'cztva ta rozvy'tku [Cooperation within the Organization for Economic Cooperation and Development] (2018). Permanent Mission of Ukraine to the UNESCO. unesco.mfa.gov.ua Retrieved from: https://unesco.mfa.gov.ua/ua/ about-ukraine/international-organizations/oesr.

10. The Global Competitiveness Report 2017-2018 (2017). Global Competitiveness Index 2017-2018, World Economic Forum. reports.weforum.org Retrieved from: http://reports.weforum.org/globalcompetitiveness-index-2017-2018. 
11. The ICT Development Index (IDI): conceptual framework and methodology (2018). www.itu.int Retrieved from: https://www.itu.int/en/ITU-D/Statistics/Pages/publications/mis2017/methodology. aspx.

12. The IMD World Digital Competitiveness Ranking 2018 (2018). IMD Center Research. www.imd.org Retrieved from: https://www.imd.org/wcc/world-competitiveness-center-rankings/ world-digital-competitiveness-rankings-2018.

13. The World Economic Forum (2018). www.weforum.org Retrieved from: .https://www.weforum.org.

A.О. Наторіна, канд. екон. наук, начальник відділу статистики і аналітики вищої освіти ДНУ «Інститут освітньої аналітики» (Київ, Украӥна).

Управління цифровим бізнесом у контексті економічного розвитку краӥни.

Ідентифіковано ключову роль інформачійно-комунікаиійних технологій у забезпеченні сталого економічного розвитку краӥни. Сформульовано і обтрунтовано доведено гіпотези про існування прямої залежності між індексом розвитку інформачійно-комунікаиійних технологій країни, цифрровою конкурентоспроможністю країни та індексом глобальної конкурентоспроможності краӥни. 3 огляду на здатність ичифрового бізнесу здійснювати суттєвий вплив на економічний розвиток краӥни, запропоновано концептуальний базис управління цифровим бізнесом (на прикладі онлайн-ритейлу). Детерміновано специфіку взаємодіі між учасниками иифрового бізнесу відповідно до фундаментальних принципів управління цифрровим бізнесом, що припускають використання відповідного інструментарію та портфелю релевантних методів управління циифровим бізнесом.

Ключові слова: економічний розвиток країни, інформаційно-комунікаційні технології, цифрова конкурентоспроможність, цифровий бізнес, концептуальний базис управління цифровим бізнесом. 